\title{
Interleukin-1 and Stroke: Biomarker, Harbinger of Damage, and Therapeutic Target
}

\author{
Adam Denes Emmanuel Pinteaux Nancy J. Rothwell Stuart M. Allan \\ Faculty of Life Sciences, University of Manchester, Manchester, UK
}

\section{Key Words}

Interleukin-1 • IL-1Ra

\begin{abstract}
Inflammation is established as a contributor to cerebrovascular disease. Risk factors for stroke include many conditions associated with chronic or acute inflammation, and inflammatory changes in the brain after cerebrovascular events contribute to outcome in experimental studies, with growing evidence from clinical research. The brain is extremely susceptible to inflammatory challenge, but resident glia, endothelial cells and neurones can all mount a pronounced inflammatory response to infection or injury. Recent discoveries highlight the importance of peripherally-derived immune cells and inflammatory molecules in various central nervous system disorders, including stroke. The inflammatory cytokine, interleukin-1 (IL-1), plays a pivotal role in both local and systemic inflammation, and is a key driver of peripheral and central immune responses to infection or injury. Inhibition of IL-1 has beneficial effects in a variety of experimental paradigms of acute brain injury and is a promising clinical target in stroke. We propose that blockade of IL-1 could be therapeutically useful in several diseases which are
\end{abstract}

risk factors for stroke, and there is already considerable preclinical and clinical evidence that inhibition of IL-1 by IL-1 receptor antagonist may be valuable in the management of acute stroke.

Copyright $\odot 2011$ S. Karger AG, Basel

\section{Introduction}

Stroke is the leading cause of neurological disability worldwide and is one of the major causes of death. Despite increased use of thrombolysis (recombinant tissue plasminogen activator, rtPA) in acute ischaemic stroke, there is still a large unmet medical need since rtPA is applicable only to a limited range of patients. The absence of new treatments is not due to lack of effort; more than a hundred potential therapies have been tested in clinical trials, without success to date. Possible reasons for such poor translation were discussed by the Stroke Therapy Academic and Industry Roundtable (STAIR) in 1999 [1]. Several STAIR recommendations followed, mostly clinical. The most recent guidelines, published in 2009 [2], were set up in response to the failure of the free radical trapping agent NXY-059. This promising treatment was

\section{KARGER \\ Fax +4161306 1234 \\ E-Mail karger@karger.ch}

www.karger.com
(C) 2011 S. Karger AG, Basel

1015-9770/11/0326-0517\$38.00/0

Accessible online at:

www.karger.com/ced
Dr. Adam Denes

Faculty of Life Sciences, University of Manchester

Manchester, M13 9PT (UK)

Tel. +44 2060502

E-Mail adam.denes@manchester.ac.uk 
believed widely to have fulfilled all the initial STAIR criteria, yet it still failed to show efficacy in the clinic. The outcome of this was STAIR VI and several other publications highlighted the need for greater rigour in preclinical stroke studies. This has been borne out by systematic review and meta-analysis of preclinical interventions, where increased experimental rigour reveals lower efficacy.

One exception is interleukin-1 receptor antagonist (IL-1Ra), as reviewed by Banwell et al. [3], in 2009. Despite concerns about certain interpretations made in this article [4], as the quality of experiment was deemed to have increased, so did the efficacy of IL-1Ra. Therefore, IL-1 appears to be a very promising target for stroke.

\section{IL-1 and Acute Brain Injury}

IL-1 is an established mediator of inflammation and damage in central nervous system (CNS) diseases in experimental studies. The IL- 1 family consists of three main ligands, the agonists IL- $1 \alpha$ and IL-1 $\beta$, and the endogenous antagonist, IL-1Ra. Most studies to date on CNS injury have focused on IL-1 $\beta$. Recent data have begun to highlight the importance of IL- $1 \alpha$, including its role as a key mediator of sterile inflammation [5], but this relates mainly to the periphery. Therefore, unless specifically stated otherwise, the term IL- 1 in this review is used to refer to IL-1 $\beta$.

Early reports showed that IL-1 is upregulated rapidly in the brain after diverse forms of experimental brain injury, which is associated with multiple inflammatory changes $[6,7]$. Intracerebroventricular [8] or intraparenchymal [9] injection of IL-1 in rodents induces neutrophil infiltration, blood-brain barrier (BBB) damage, astrogliosis and neovascularisation. Blockade of IL-1 action using recombinant IL-1Ra reduces brain damage in focal cerebral ischaemia, traumatic and excitotoxic injury in rodents, identifying endogenous IL-1 as an important mediator of experimental brain damage [10]. The role of IL-1 was confirmed by many subsequent studies, using transgenic animals (knock-out mice for most IL-1 family members exist) or by blocking IL-1 production and/or actions. For example, ischaemic brain injury is markedly reduced in IL- $1 \alpha / \beta$-deficient $(-/-)$ mice $[11,12]$, a selective IL-1 $\beta$ antibody reduces ischaemic damage after transient middle cerebral artery occlusion (MCAo) in rat [13], and caspase-1 inhibitors (which prevent IL-1 processing and release) reduce brain damage in focal cerebral is- chaemia [14-16]. Similarly, caspase-1 inhibitors are protective in experimental models of subarachnoid haemorrhage (SAH), and prevent neurogenic pulmonary oedema after SAH $[17,18]$. Inhibition of the neuronal NLRP1 inflammasome (which is involved in the processing and release of IL- 1 through the activation of caspase-1) improves outcome after stroke, traumatic or spinal cord injury [19-21]. Further support for a role for IL-1 in stroke comes from the observations that IL-1 or IL-1Ra gene polymorphisms are associated with altered susceptibility to stroke, carotid atherosclerosis and intracranial haemorrhage in humans [22-27].

\section{Mechanisms of IL-1 Action in CNS Inflammation after Stroke}

The mechanisms of IL-1 actions on neuroinflammation in response to stroke are complex. In vivo and in vitro studies in animals show that all resident brain cells and invading immune cells that have been implicated in stroke can produce and/or respond to IL-1 (see [28] for review). Some of these studies suggest new mechanisms of IL-1 actions that can possibly occur independently of classical IL-1 receptors and signaling pathways, although this has to be further investigated.

IL-1 acts via its functional type 1 receptor, IL-1R1, which is expressed by all brain cells with the apparent exception of microglia [29], and recruits an accessory protein (IL-1RAcP) for signalling (fig. 1). IL-1RAcP increases the binding affinity of IL-1 to IL-1R1 $[30,31]$ and recruits downstream adaptor proteins such as the myeloid differentiation factor 88 (MyD88) and IL-1R-associated kinase(s) (IRAK) [32, 33]. IL-1RAcP is expressed constitutively throughout the brain by both neurones and astrocytes [34]. A recently identified isoform, IL-1RAcPb, seems to be expressed exclusively by neurones [35]. IL$1 \mathrm{RAcPb}$ does not mediate canonical IL-1 responses, but modulates neuronal gene expression and IL-1-induced neuroinflammatory responses [35]. In neurones, IL-1 induces fast electrophysiological and febrile responses (within minutes) in an IL-1R1- and MyD88-dependent manner, which is mediated through activation of ceramide and Src independently of gene expression [36-38]. The neuromodulatory effect of IL-1 seems to be highly dose-dependent; lower concentrations induce depolarization, and higher concentrations induce hyperpolarization and synaptic transmission inhibition [39]. IL-1 also regulates N-methyl-D-aspartic acid (NMDA) receptor phosphorylation, calcium influx and mediates excitotox- 


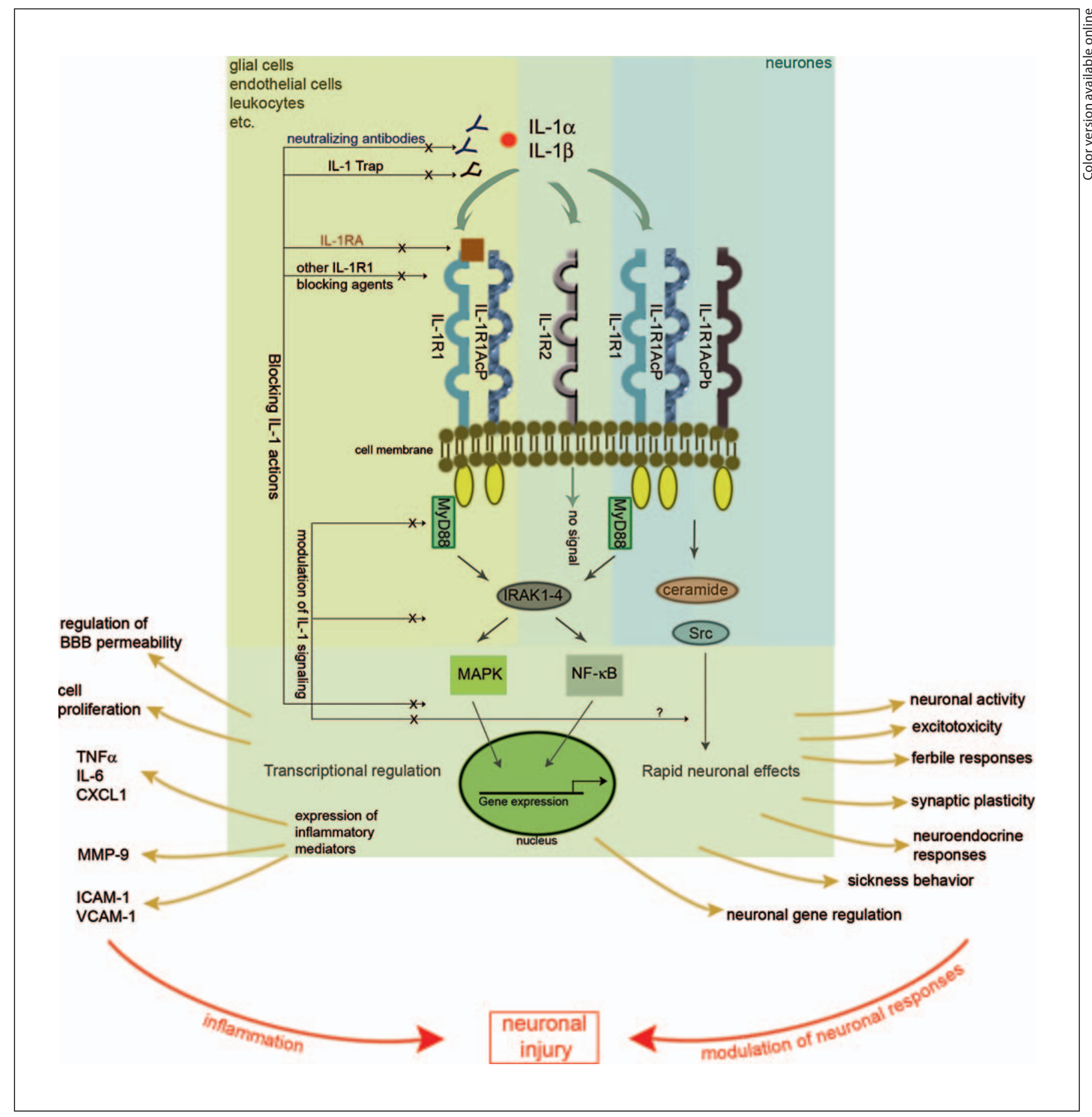

Fig. 1. Mechanisms and blockade of IL-1 actions. IL-1 exerts multiple effects on different cell types through IL-1R1, both in the periphery and the CNS. As key mediators of inflammation, both IL- $1 \alpha$ and IL-1 $\beta$ induce expression of various inflammatory cytokines, adhesion molecules and a diverse array of other inflammatory substances. In the brain in response to injury or infection, these processes lead to altered BBB permeability, glial proliferation and recruitment of resident and blood-borne inflammatory cells. Via its neuronal actions, IL-1 influences several physiologi- cal processes such as synaptic plasticity, neuronal activity or memory formation, but can also mediate pathological actions such as excitotoxicity. In disease, IL-1-mediated inflammatory and neuronal responses can lead to neuronal injury. Interventions against IL-1 binding to its receptor (by antibody neutralization, IL-1 Trap or IL-1RA) or IL-1 signalling cascades have been shown to confer neuroprotection in multiple brain injury models. See detailed information in the text. 
icity [40-42]. A second IL-1 type 2 receptor, IL-1R2, has no intracellular domain and is believed to act primarily as a soluble decoy receptor.

IL-1 is not directly toxic to healthy neurones in vitro or in vivo, but appears to cause neuronal death indirectly through actions on astrocytes and brain endothelial cells. IL-1 activates astrocytes via IL-1R1 and the classic mitogen-activated kinase (MAPK)/nuclear factor-kappa B (NF- $\kappa B$ ) signalling pathways [43] leading to production of neurotoxic, neuroprotective and inflammatory mediators including IL-6, tumour necrosis factor- $\alpha$ (TNF- $\alpha$ ) and various chemokines that influence CNS inflammation. IL-1 also induces astrogliosis, an important cellular response for the formation of glial scarring [44]. However, IL-1-induced astrogliosis is also accompanied by increased astrocytic matrix-metalloproteinase-9 (MMP-9) activity that can induce or contribute to neuronal death [45].

The brain endothelium is a primary target of IL-1. IL-1 activates brain endothelial cells via binding to IL$1 \mathrm{R} 1$ and activation of MAPK/NF- $\kappa \mathrm{B}$ pathways, leading to endothelial expression of intercellular adhesion molecule (ICAM)-1 and vascular cell adhesion molecule (VCAM)-1 and release of various chemokines, including CXCL1, which in turn leads to neutrophil adhesion/infiltration [46]. Intracerebroventricular administration of IL-1 in mice induces activation of the cerebrovascular endothelium, leading to leucocyte infiltration, which is inhibited by selective deletion of IL-1R1 in endothelia [47]. IL-1 also activates the brain endothelium to cause breakdown of endothelial tight junctions, leading to loss of BBB integrity [41] that may influence neutrophil recruitment into the brain tissue and subsequent neuronal injury. IL-1 is also a potent inducer of neuronal chemokines which may influence local microglia responses and the acute neuroinflammatory response [48]. Thus, IL-1 can mediate the central inflammatory response through actions on all brain cells. However, the contribution of each cellular response will vary temporally and spatially depending on the nature/ severity of the insult and underlying inflammatory status of the individual.

\section{Role of IL-1 in Systemic Inflammatory Disease and Co-Morbidities for Stroke}

In humans, several seemingly unrelated 'auto-inflammatory' diseases that manifest in the periphery can be effectively treated with neutralization of IL-1 $\beta$ or IL-1R1 blockade. These include gout, osteoarthritis, type-2 diabetes and post-myocardial infarction heart failure [4951]. Systemic inflammatory diseases, characterized by recurrent fevers, leucocytosis, anaemia, and elevated acutephase proteins are linked to IL-1 activity [52]. IL-1 is an important endogenous pyrogen, and induces multiple autonomic responses including activation of the sympathetic nervous system and the hypothalamic-pituitaryadrenal (HPA) axis, release of vasopressin, and increases in blood pressure and heart rate [53-56].

Growing evidence also implicates IL-1 as an important contributor to several conditions that are common risk factors for cerebrovascular diseases (fig. 2). Major causative factors in stroke include atherosclerosis, hypertension, diabetes, obesity and infection, all known to involve chronic or acute inflammation $[57,58]$. A key role for the NLRP3 inflammasome, which mediates caspase- 1 activation and IL-1 $\beta$ processing and release, has been confirmed recently in experimental models of obesity and atherosclerosis $[59,60]$. Ingestion of a high-fat diet has multiple proinflammatory effects and is a key driver of atherosclerosis and obesity. Palmitate (a saturated fatty acid) induces activation of the NLRP3 inflammasome and impairs insulin signalling in several target tissues to reduce glucose tolerance and insulin sensitivity [61]. Similarly, IL-1 regulates multiple atherogenic processes induced by feeding high-fat diets in mice. Selective loss of IL-1 signalling reduces plaque burden and blood pressure in high-fat-fed ApoE-/- $\times$ IL-1R1-/- (double knock out) mice [62].

Atherosclerosis and obesity are independent risk factors for stroke, but until recently it was not clear whether these chronic peripheral conditions alone may induce inflammatory changes in the brain. We have confirmed that an atherogenic diet induces microglial and vascular activation in the brain parenchyma, resulting in infiltration of leucocytes into the choroid plexus in ApoE-/mice (which develop advanced atherosclerosis in response to high-fat feeding), in the absence of any experimental brain injury [63]. Neuroinflammatory changes have also been observed in aged, obese and atherosclerotic corpulent rats (which have a natural mutation of the leptin receptor). Furthermore, we have found increased inflammation in the brain by using positron emission tomography in a small group of patients at risk of stroke (multiple risk factors for stroke and chronically elevated C-reactive protein; CRP), but without any neurological symptoms or brain injury detectable by magnetic resonance imaging (MRI) [63]. 


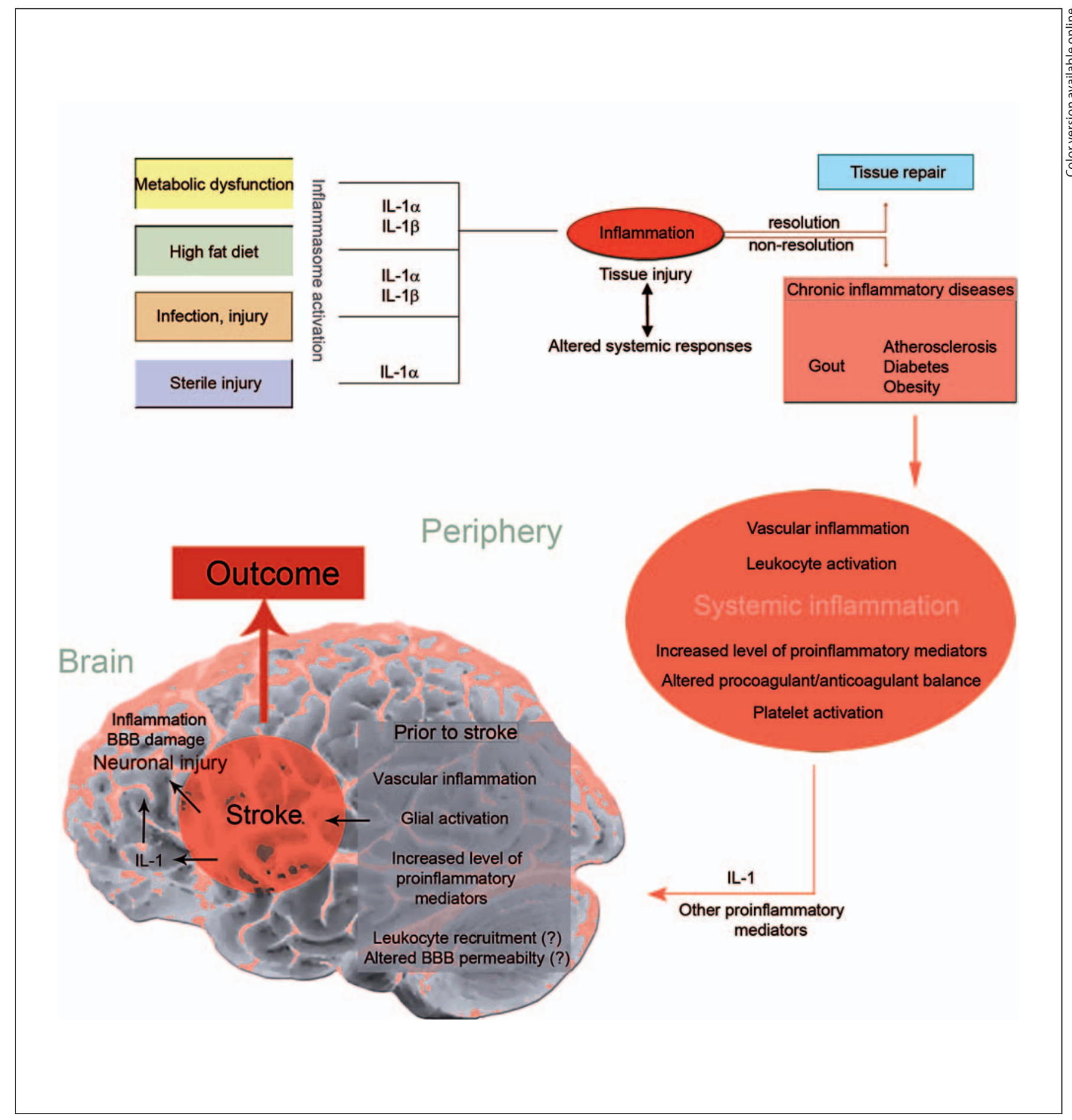

Fig. 2. The role of IL-1 in systemic inflammatory diseases and stroke. Injury, infection, high-fat containing diet and other metabolic alterations can induce the expression of IL- $1 \alpha$, IL- $1 \beta$ and can drive inflammasome activation and IL-1 $\beta$ processing/release. Non-resolving inflammation can lead to chronic inflammatory diseases, several of which - such as atherosclerosis, obesity or diabetes - involve systemic inflammatory changes and contribute to stroke. Chronic inflammatory diseases are associated with in- duction of inflammatory mediators, vascular inflammation, activation of different leucocyte subsets and platelets in the periphery. Systemic inflammation is associated with vascular and glial activation which primes and renders the brain susceptible to a subsequent cerebrovascular event. After stroke, central and peripheral IL-1 and other proinflammatory cytokines contribute to neuronal injury and overall outcome. See detailed information in the text. 
The contribution of IL-1 to an atherogenic diet-induced brain inflammation in mice is supported by a markedly reduced leucocyte infiltration, microglial and vascular activation in high-fat-fed ApoE-/- $\times$ IL-1R1-/mice compared to IL-1 responsive ApoE-/- animals [unpubl. data].

As well as contributing to chronic inflammatory disease that contributes to stroke risk, IL-1 may also have a key role in acute systemic inflammatory challenges, such as infection. Experimentally this is supported by data showing peripheral administration of lipopolysaccharide (LPS) or IL-1 exacerbates neuronal death and BBB breakdown in response to experimental stroke in mice, which is prevented by IL-1Ra [64]. This exacerbation of the ischaemic brain damage is prevented by neutrophil depletion or MMP-9 blockade [64, 65]. IL-1 is a potent inducer of vascular activation, and neutrophils are also highly responsive to IL-1. The systemic effects of IL-1 on increased BBB breakdown after stroke may be explained by increased neutrophil recruitment to the ischaemic hemisphere, where breakdown of tight junction proteins is promoted by neutrophil-derived MMP$9[64,65]$. IL-1 also potentiates acute-phase responses and expression of CXC chemokines after experimental stroke in mice [64]. IL-1 produced locally by perivascular macrophages influences the cerebrovascular endothelium [66], and our recent data indicate that platelets are an important source of IL- $1 \alpha$, which promotes vascular activation and neutrophil recruitment to the brain [67].

The results presented above indicate that peripherallyderived IL-1 is a key driver of several common risk factors of stroke, and also contributes directly to acute brain injury that is exacerbated by systemic inflammatory conditions.

\section{Infection and Stroke: A Role for IL-1 and Other Proinflammatory Mediators?}

Pre- or post-stroke infections are associated with poor outcome in patients $[57,58]$. There are several potential mechanisms whereby infections may affect stroke outcome, such as increased circulating inflammatory factors, coagulation or microvascular injury in the brain. Infections are associated with elevated platelet activation and increased platelet-leucocyte aggregation in stroke patients [68]. IL-1 and other pro-inflammatory factors such as IL- 6 and TNF- $\alpha$ derived from activated leukocytes, are known to promote coagulation [69-73]. In an experimen- tal model of chronic systemic infection, increased brain damage was associated with increased platelet aggregation and microvascular injury [74]. Similarly, influenza is a significant risk factor for poor outcome in human stroke and a recent experimental study demonstrated increased ischaemic brain damage and microvascular MMP-9 expression in mice with influenza infection [75-77]. Both these experimental studies of infection identified a proinflammatory chemokine, CCL5 (which can be induced by IL-1 or interferon- $\gamma$ ), as a candidate mediator of the systemic effects of infection on brain injury [74, 77].

Patients with pneumonia develop a systemic cytokine response and show elevated circulating IL-1 concentrations [78-80], whilst sterile lung injury, pneumonia induced lung injury, or resistance against pneumococcal infection appear to be mediated by IL-1 in experimental rodent models [81-83]. Elevated circulating IL-1Ra concentrations are also associated with increased levels of infection in patients with respiratory disease [79, 84, 85] and with post-stroke infection [86]. This may indicate that increased IL-1 activity and reduced host defence against the infectious agents occur.

The examples above indicate that IL-1 and other systemic inflammatory factors may contribute to the impact of infection on ischaemic brain injury. Further research is required to determine the specific role of IL- 1 crosstalk mechanisms between acute and chronic inflammatory conditions and cerebrovascular disease.

\section{IL-1 and Stroke Induced Immunosuppression}

Acute IL-1 treatment can lead to suppression of certain peripheral immune responses. Patients respond to IL-1 administration with multiple endocrine changes, including cortisol secretion [87]. Intracerebroventricular infusion of femtomolar quantities of IL-1 in rodents and primates or increases of endogenous IL-1 in the brain activates the HPA axis, increases the secretion of cortisol, and decreases cellular immune responses, NK cell activity, the response to mitogen, as well as IL-2 production of splenic and blood lymphocytes. These effects are partly dependent on sympathetic nervous system activity and the release of corticotropin-releasing hormone $(\mathrm{CRH})$ $[88,89]$. Corticosteroids may be important to counterbalance the systemic effects of IL-1 as adrenalectomised mice show increased anorexia and mortality in response to IL-1 [90]. Exposure to LPS (acts on Toll-like receptor 4, which shares several common signalling cascades with IL-1) induces a transient unresponsive state of cells to 
subsequent LPS re-stimulation, a phenomenon known as endotoxin tolerance. This occurs via dysregulation of LPS-induced Toll-like receptor 4-MyD88 complex formation and IRAK-1 activation in monocytes [91]. Acute administration of endotoxin in various species stimulates adrenocorticotropic hormone (ACTH) and cortisol secretion and the release of $\mathrm{CRH}$ and vasopressin (AVP) in the hypophysial portal blood [92]. It is not clear whether immunosuppression and infections after stroke are linked directly to altered IL-1 activity. Nevertheless, IL$1 \mathrm{Ra}$ reverses stroke-induced peripheral immunosuppression in patients [93] and also reduces stroke-induced elevation of cortisol in the blood [Smith and Hopkins, pers. commun.].

\section{Current Interventions and New Approaches to Inhibit IL-1 in Inflammatory Disease}

Numerous pre-clinical studies have proposed the IL-1 system as a valid therapeutic target in acute and chronic inflammatory diseases and clinical stroke. Current strategies target IL-1 expression using caspase-1/NALP3 inhibitors, release of IL-1 using Rilonacept (also known as IL-1 Trap, dimeric recombinant extracellular domain of the IL-1R1/IL-1RAcP fused to human IgG1), canakinumab and XOMA052 (human IL-1 $\beta$-specific blocking antibodies), and Anakinra (recombinant non-glycosylated human IL-1Ra) (see [94] for review).

IL-Ra is the most advanced therapeutic approach to date, since it is in clinical use for rheumatoid arthritis and other conditions and has been studied in clinical trials of ischaemic stroke and SAH. Nevertheless, there may be a need for developing further approaches to block IL-1 effects in acute and chronic diseases. Although our pharmacokinetic studies indicated sustained IL-1Ra levels for several hours after peripheral (subcutaneous or intravenous) injection, the brain penetration of IL-1RA may be limited and repeated administration for prolonged actions may be clinically very expensive. Furthermore, IL-1Ra does not block all actions of IL-1 on brain cells, including glia and neurones [43, 95]. In addition, IL-1-induced brain damage in IL1R1-/- mice is not blocked by central IL-1Ra administration [11], suggesting the possible expression of additional brain-specific IL-1 receptors which are not affected by IL-1Ra. A recent study found that $I L-1 R 1$ gene expression is regulated by 7 putative novel promoters, one of which could lead to the expression of a truncated IL-1R1 which could bind IL-1 for signalling [96]. These new insights into the regulation of IL-1R1 expression could explain earlier observations of IL-1R1-independent IL-1 actions in stroke.

A number of additional approaches to inhibiting IL-1 are in development. A small-molecular-weight inhibitor of IL-1 receptor complex (RYTVELA), designed from the IL-1RAcP sequence to block IL-1R1, has been developed [97]. Its specificity for IL-1R1, has been demonstrated [98] and its potential application in acute neuroinflammation after stroke remains to be determined. The current aim now is to fully understand the mechanism of receptor complex assembly by NMR analysis for the development of new small inhibitors. Indeed, the 3D structure of IL-1 bound to IL-1R2 and IL-1RAcP has recently been unravelled [99], but resolving the mechanism of IL-1R1 and IL1RAcP assembly will be critical for the development of future therapeutic strategies.

\section{IL-1Ra: Meeting the STAIR Criteria}

The quality of experimental stroke studies and the interpretation of their results have been suggested as a major factor in the failure of several stroke trials [100]. The STAIR criteria address several important issues and recommends guidelines regarding preclinical neuroprotective and restorative drug development $[1,2]$. In light of these guidelines, IL-1Ra seems a promising therapeutic target in stroke.

IL-1Ra has the advantages of specificity, absence of safety concerns in patients and extensive pre-clinical studies $[4,101,102]$. In a small phase 2 clinical study of stroke, IL-1Ra was safe. The study was not powered to detect efficacy, but clinical outcomes were promising [103]. IL-1Ra is well established as a treatment for rheumatoid arthritis, where it appears to be safe and well tolerated [104]. Peripheral administration (single bolus followed by infusion) of IL-1Ra is neuroprotective in rats after MCAo, and IL-1Ra plasma and CSF concentration reach therapeutic concentrations that are similar to those obtained in SAH patients treated with IL-1Ra [105]. Indeed, the pharmacokinetic properties of IL-1Ra in SAH patients is now well established [106]. IL-1Ra administered subcutaneously in rat reaches the brain tissue and is neuroprotective after MCAo [107], and intravenous administration of IL-1Ra leads to concentrations in the CSF of SAH patients that are neuroprotective in rodents [108].

These translational studies indicate that IL-1Ra can be used safely in clinical stoke settings with the prediction 
of good efficacy. Apart from intravenous and subcutaneous administration (see above), the feasibility of efficient aerosol delivery of the human IL-1Ra for reduction of acute lung inflammation has been demonstrated recently in mice [109].

A recent meta-analysis of IL-1Ra in pre-clinical studies indicated an average of $38.2 \%$ reduction in infarct volume through 16 published and one unpublished data sources [3]. It was stated that no studies to date have used animals with hypertension or diabetes or tested efficacy of administration beyond $3 \mathrm{~h}$ [3]. We have now performed a series of experiments to investigate the effi- cacy of IL-1Ra in co-morbid animals. IL-1Ra administered subcutaneously at reperfusion to aged corpulent rats and aged lean controls results in an approximately $50 \%$ reduction in infarct volume and BBB breakdown after transient MCAo [110]. Subcutaneous injection of IL-1Ra also leads to a $31 \%$ reduction of infarct volume in aged lean rats with $3 \mathrm{~h}$ delayed administration [Pradillo, unpubl. data].

In conclusion, IL-1RA appears to be a promising treatment regimen in stroke and on-going research aims to strengthen existing evidence about its therapeutic potential.

\section{References}

$\checkmark 1$ Recommendations for standards regarding preclinical neuroprotective and restorative drug development. Stroke 1999;30:27522758.

$\checkmark 2$ Fisher M, Feuerstein G, Howells DW, Hurn PD, Kent TA, Savitz SI, Lo EH: Update of the stroke therapy academic industry roundtable preclinical recommendations. Stroke 2009;40:2244-2250.

3 Banwell V, Sena ES, Macleod MR: Systematic review and stratified meta-analysis of the efficacy of interleukin-1 receptor antagonist in animal models of stroke. J Stroke Cerebrovasc Dis 2009;18:269-276.

4 Parry-Jones A, Boutin H, Denes A, McColl B, Hopkins S, Allan S, Tyrrell P: Interleukin-1 receptor antagonist in animal models of stroke: a fair summing up? J Stroke Cerebrovasc Dis 2010;19:512-513.

5 Chen CJ, Kono H, Golenbock D, Reed G, Akira S, Rock KL: Identification of a key pathway required for the sterile inflammatory response triggered by dying cells. $\mathrm{Na}$ ture medicine 2007;13:851-856

6 Giulian D, Lachman LB: Interleukin-1 stimulation of astroglial proliferation after brain injury. Science 1985;228:497-499.

$\checkmark 7$ Woodroofe MN, Sarna GS, Wadhwa M, Hayes GM, Loughlin AJ, Tinker A, Cuzner ML: Detection of interleukin-1 and interleukin- 6 in adult rat brain, following mechanical injury, by in vivo microdialysis: evidence of a role for microglia in cytokine production. J Neuroimmunol 1991;33:227-236.

>8 Quagliarello VJ, Wispelwey B, Long WJ Jr, Scheld WM: Recombinant human interleukin-1 induces meningitis and blood-brain barrier injury in the rat: characterization and comparison with tumor necrosis factor. J Clin Invest 1991;87:1360-1366.

$>9$ Giulian D, Woodward J, Young DG, Krebs JF, Lachman LB: Interleukin-1 injected into mammalian brain stimulates astrogliosis and neovascularization. J Neurosci 1988;8: 2485-2490

\section{Relton JK, Rothwell NJ: Interleukin-1 recep- tor antagonist inhibits ischaemic and excito- toxic neuronal damage in the rat. Brain Res Bull 1992;29:243-246. \\ 11 Touzani O, Boutin H, LeFeuvre R, Parker L, Miller A, Luheshi G, Rothwell N: Interleu- kin-1 influences ischemic brain damage in the mouse independently of the interleu- kin-1 type i receptor. J Neurosci 2002;22:38- 43. \\ 12 Boutin H, LeFeuvre RA, Horai R, Asano M, Iwakura Y, Rothwell NJ: Role of IL-1alpha and IL-1beta in ischemic brain damage. J Neurosci 2001;21:5528-5534.}

13 Yamasaki Y, Matsuura N, Shozuhara H, Onodera H, Itoyama Y, Kogure K: Interleukin-1 as a pathogenetic mediator of ischemic brain damage in rats. Stroke 1995;26:676680.

14 Ross J, Brough D, Gibson RM, Loddick SA, Rothwell NJ: A selective, non-peptide caspase-1 inhibitor, vrt-018858, markedly reduces brain damage induced by transient ischemia in the rat. Neuropharmacology 2007;53:638-642.

15 Loddick SA, MacKenzie A, Rothwell NJ: An ICE inhibitor, $\mathrm{z}$-vad-dcb attenuates ischaemic brain damage in the rat. Neuroreport 1996;7:1465-1468

16 Li H, Colbourne F, Sun P, Zhao Z, Buchan AM, Iadecola C: Caspase inhibitors reduce neuronal injury after focal but not global cerebral ischemia in rats. Stroke 2000;31:176182.

17 Wu B, Ma Q, Khatibi N, Chen W, Sozen T, Cheng O, Tang J: Ac-yvad-cmk decreases blood-brain barrier degradation by inhibiting caspase- 1 activation of interleukin-1beta in intracerebral hemorrhage mouse model. Translational Stroke Res 2010;1:57-64.

18 Suzuki H, Sozen T, Hasegawa Y, Chen W, Zhang JH: Caspase-1 inhibitor prevents neurogenic pulmonary edema after subarachnoid hemorrhage in mice. Stroke 2009;40 3872-3875.
19 de Rivero Vaccari JP, Lotocki G, Marcillo AE, Dietrich WD, Keane RW: A molecular platform in neurons regulates inflammation after spinal cord injury. J Neurosci 2008;28: 3404-3414.

20 de Rivero Vaccari JP, Lotocki G, Alonso OF, Bramlett HM, Dietrich WD, Keane RW: Therapeutic neutralization of the nlrp1 inflammasome reduces the innate immune response and improves histopathology after traumatic brain injury. J Cereb Blood Flow Metab 2009;29:1251-1261.

21 Abulafia DP, de Rivero Vaccari JP, Lozano JD, Lotocki G, Keane RW, Dietrich WD: Inhibition of the inflammasome complex reduces the inflammatory response after thromboembolic stroke in mice. J Cereb Blood Flow Metab 2009;29:534-544.

-22 Worrall BB, Azhar S, Nyquist PA, Ackerman RH, Hamm TL, DeGraba TJ: Interleukin-1 receptor antagonist gene polymorphisms in carotid atherosclerosis. Stroke 2003;34:790793.

23 Um JY, Moon KS, Lee KM, Yun JM, Cho KH, Moon BS, Kim HM: Association of interleukin-1 alpha gene polymorphism with cerebral infarction. Brain Res 2003;115:50-54.

24 Dziedzic T, Slowik A, Pera J, Szczudlik A: Interleukin 1 beta polymorphism $(-511)$ and risk of stroke due to small vessel disease. Cerebrovasc Dis 2005;20:299-303.

25 Kim H, Hysi PG, Pawlikowska L, Poon A, Burchard EG, Zaroff JG, Sidney S, Ko NU, Achrol AS, Lawton MT, McCulloch CE, Kwok PY, Young WL: Common variants in interleukin-1-beta gene are associated with intracranial hemorrhage and susceptibility to brain arteriovenous malformation. Cerebrovasc Dis 2009;27:176-182.

-26 Seripa D, Dobrina A, Margaglione M, Matera MG, Gravina C, Vecile E, Fazio VM: Relevance of interleukin-1 receptor antagonist intron-2 polymorphism in ischemic stroke. Cerebrovasc Dis 2003;15:276-281. 
-27 Rezaii AA, Hoseinipanah SM, Hajilooi M, Rafiei AR, Shikh N, Haidari M: Interleukin-1 receptor antagonist gene polymorphism and susceptibility to ischemic stroke. Immunol Invest 2009;38:220-230.

-28 Pinteaux E, Trotter P, Simi A: Cell-specific and concentration-dependent actions of interleukin-1 in acute brain inflammation. Cytokine 2009;45:1-7.

-29 Pinteaux E, Parker LC, Rothwell NJ, Luheshi GN: Expression of interleukin-1 receptors and their role in interleukin-1 actions in murine microglial cells. J Neurochem 2002;83: 754-763.

-30 Greenfeder SA, Nunes P, Kwee L, Labow M, Chizzonite RA, Ju G: Molecular cloning and characterization of a second subunit of the interleukin 1 receptor complex. J Biol Chem 1995;270:13757-13765.

-31 Greenfeder SA, Varnell T, Powers G, Lombard-Gillooly K, Shuster D, McIntyre KW, Ryan DE, Levin W, Madison V, Ju G: Insertion of a structural domain of interleukin (IL)-1 beta confers agonist activity to the IL-1 receptor antagonist. Implications for IL-1 bioactivity. J Biol Chem 1995;270:22460-22466.

>32 Huang J, Gao X, Li S, Cao Z: Recruitment of Irak to the interleukin 1 receptor complex requires interleukin 1 receptor accessory protein. Proc Natl Acad Sci USA 1997;94:1282912832.

-33 Volpe F, Clatworthy J, Kaptein A, Maschera B, Griffin AM, Ray K: The IL1 receptor accessory protein is responsible for the recruitment of the interleukin-1 receptor associated kinase to the IL1/IL1 receptor i complex. FEBS Lett 1997;419:41-44.

-34 Gabellec MM, Jafarian-Tehrani M, Griffais R, Haour F: Interleukin-1 receptor accessory protein transcripts in the brain and spleen: kinetics after peripheral administration of bacterial lipopolysaccharide in mice. Neuroimmunomodulation 1996;3:304-309.

- 35 Smith DE, Lipsky BP, Russell C, Ketchem RR, Kirchner J, Hensley K, Huang Y, Friedman WJ, Boissonneault V, Plante MM, Rivest S, Sims JE: A central nervous systemrestricted isoform of the interleukin-1 receptor accessory protein modulates neuronal responses to interleukin-1. Immunity 2009;30: 817-831.

-36 Davis CN, Tabarean I, Gaidarova S, Behrens MM, Bartfai T: IL-1beta induces a myd88dependent and ceramide-mediated activation of src in anterior hypothalamic neurons. J Neurochem 2006;98:1379-1389.

37 Sanchez-Alavez M, Tabarean IV, Behrens MM, Bartfai T: Ceramide mediates the rapid phase of febrile response to IL-1beta. Proc Natl Acad Sci USA 2006;103:2904-2908.

-38 Viviani B, Bartesaghi S, Gardoni F, Vezzani A, Behrens MM, Bartfai T, Binaglia M, Corsini E, Di Luca M, Galli CL, Marinovich M: Interleukin-1beta enhances NMDA receptor-mediated intracellular calcium increase through activation of the src family of kinases. J Neurosci 2003;23:8692-8700.
39 Desson SE, Ferguson AV: Interleukin 1beta modulates rat subfornical organ neurons as a result of activation of a non-selective cationic conductance. J Physiol 2003;550:113122.

40 Sama MA, Mathis DM, Furman JL, Abdul HM, Artiushin IA, Kraner SD, Norris CM: Interleukin-1beta-dependent signaling between astrocytes and neurons depends critically on astrocytic calcineurin/nfat activity. J Biol Chem 2008;283:21953-21964.

41 Bolton SJ, Anthony DC, Perry VH: Loss of the tight junction proteins occludin and zonula occludens-1 from cerebral vascular endothelium during neutrophil-induced blood-brain barrier breakdown in vivo. Neuroscience 1998;86:1245-1257.

42 Fogal B, Hewett SJ: Interleukin-1beta: a bridge between inflammation and excitotoxicity? J Neurochem 2008;106:1-23.

43 Parker LC, Luheshi GN, Rothwell NJ, Pinteaux E: IL-1 beta signalling in glial cells in wildtype and IL-1ri deficient mice. Br J Pharmacol 2002;136:312-320.

44 Herx LM, Yong VW: Interleukin-1 beta is required for the early evolution of reactive astrogliosis following CNS lesion. J Neuropathol Exp Neurol 2001;60:961-971.

45 Thornton P, Pinteaux E, Allan SM, Rothwel NJ: Matrix metalloproteinase- 9 and urokinase plasminogen activator mediate interleukin-1-induced neurotoxicity. Mol Cell Neurosci 2008;37:135-142.

46 Thornton P, McColl BW, Cooper L, Rothwell NJ, Allan SM: Interleukin-1 drives cerebrovascular inflammation via map kinase-independent pathways. Curr Neurovasc Res 2011;7:330-340.

47 Ching S, Zhang H, Belevych N, He L, Lai W, Pu XA, Jaeger LB, Chen Q, Quan N: Endothelial-specific knockdown of interleukin-1 (IL-1) type 1 receptor differentially alters CNS responses to IL-1 depending on its route of administration. J Neurosci 2007;27: 10476-10486.

48 Tsakiri N, Kimber I, Rothwell NJ, Pinteaux E: Differential effects of interleukin-1 alpha and beta on interleukin- 6 and chemokine synthesis in neurones. Mol Cell Neurosci 2008;38:259-265.

49 Dinarello CA: Interleukin-1 in the pathogenesis and treatment of inflammatory diseases. Blood 2011;117:3720-3732.

50 Dinarello CA: Blocking interleukin-1beta in acute and chronic autoinflammatory diseases. J Intern Med 2011;269:16-28.

51 Donath MY, Shoelson SE: Type 2 diabetes as an inflammatory disease. Nat Rev 2011;11: 98-107.

52 Dinarello CA: Blocking IL-1 in systemic inflammation. J Exp Med 2005;201:1355-1359.

53 Rothwell NJ: CNS regulation of thermogenesis. Crit Rev Neurobiol 1994;8:1-10.
54 Takahashi H, Nishimura M, Sakamoto M, Ikegaki I, Nakanishi T, Yoshimura M: Effects of interleukin-1 beta on blood pressure, sympathetic nerve activity, and pituitary endocrine functions in anesthetized rats. Am J Hypertens 1992;5:224-229.

55 Niijima A, Hori T, Aou S, Oomura Y: The effects of interleukin-1 beta on the activity of adrenal, splenic and renal sympathetic nerves in the rat. J Autonom Nerv Syst 1991; 36:183-192.

56 Kannan H, Tanaka Y, Kunitake T, Ueta Y, Hayashida Y, Yamashita H: Activation of sympathetic outflow by recombinant human interleukin-1 beta in conscious rats. Am J Physiol 1996;270:R479-R485.

57 McColl BW, Allan SM, Rothwell NJ: Systemic infection, inflammation and acute ischemic stroke. Neuroscience 2009;158:10491061.

58 Denes A, Thornton P, Rothwell NJ, Allan SM: Inflammation and brain injury: acute cerebral ischaemia, peripheral and central inflammation. Brain Behav Immunity 2010; 24:708-723

59 Vandanmagsar B, Youm YH, Ravussin A, Galgani JE, Stadler K, Mynatt RL, Ravussin E, Stephens JM, Dixit VD: The nlrp3 inflammasome instigates obesity-induced inflammation and insulin resistance. Nat Med 2011; 17:179-188.

60 Duewell P, Kono H, Rayner KJ, Sirois CM, Vladimer G, Bauernfeind FG, Abela GS, Franchi L, Nunez G, Schnurr M, Espevik T, Lien E, Fitzgerald KA, Rock KL, Moore KJ, Wright SD, Hornung V, Latz E: Nlrp3 inflammasomes are required for atherogenesis and activated by cholesterol crystals. $\mathrm{Na}$ ture 2010;464:1357-1361.

61 Wen H, Gris D, Lei Y, Jha S, Zhang L, Huang MT, Brickey WJ, Ting JP: Fatty acid-induced nlrp3-asc inflammasome activation interferes with insulin signaling. Nat Immunol 2011;12:408-415.

62 Chamberlain J, Francis S, Brookes Z, Shaw G, Graham D, Alp NJ, Dower S, Crossman DC: Interleukin-1 regulates multiple atherogenic mechanisms in response to fat feeding. PloS One 2009;4:e5073.

63 Drake C, Boutin H, Jones MS, et al: Brain inflammation is induced by co-morbidities and risk factors for stroke. Brain Behav Immunity 2011;25:1113-1122.

64 McColl BW, Rothwell NJ, Allan SM: Systemic inflammatory stimulus potentiates the acute phase and cxc chemokine responses to experimental stroke and exacerbates brain damage via interleukin-1- and neutrophildependent mechanisms. J Neurosci 2007;27: 4403-4412.

65 McColl BW, Rothwell NJ, Allan SM: Systemic inflammation alters the kinetics of cerebrovascular tight junction disruption after experimental stroke in mice. J Neurosci 2008;28:9451-9462. 
-66 Konsman JP, Drukarch B, Van Dam AM: (Peri)vascular production and action of proinflammatory cytokines in brain pathology. Clin Sci (Lond) 2007;112:1-25.

67 Thornton P, McColl BW, Greenhalgh A, Denes A, Allan SM, Rothwell NJ: Platelet interleukin-1alpha drives cerebrovascular inflammation. Blood 2010;115:3632-3639.

68 Zeller JA, Lenz A, Eschenfelder CC, Zunker P, Deuschl G: Platelet-leukocyte interaction and platelet activation in acute stroke with and without preceding infection. Arterioscler Thromb Vasc Biol 2005;25:1519-1523.

69 van der Poll T, Levi M, Hack CE, et al: Elimination of interleukin 6 attenuates coagulation activation in experimental endotoxemia in chimpanzees. J Exp Med 1994;179:12531259.

70 van der Poll T, Levi M, Buller HR, van Deventer SJ, de Boer JP, Hack CE, ten Cate JW: Fibrinolytic response to tumor necrosis factor in healthy subjects. J Exp Med 1991;174: 729-732.

71 Dejana E, Breviario F, Erroi A, et al: Modulation of endothelial cell functions by different molecular species of interleukin 1. Blood 1987;69:695-699.

72 Shebuski RJ, Kilgore KS: Role of inflammatory mediators in thrombogenesis. J Pharmacol Exp Ther 2002;300:729-735.

73 Jansen PM, Boermeester MA, Fischer E, de Jong IW, van der Poll T, Moldawer LL, Hack CE, Lowry SF: Contribution of interleukin-1 to activation of coagulation and fibrinolysis, neutrophil degranulation, and the release of secretory-type phospholipase A2 in sepsis: studies in nonhuman primates after interleukin-1 alpha administration and during lethal bacteremia. Blood 1995;86:1027-1034.

-74 Denes A, Humphreys N, Lane TE, Grencis R, Rothwell N: Chronic systemic infection exacerbates ischemic brain damage via a ccl5 (regulated on activation, normal T-cell expressed and secreted)-mediated proinflammatory response in mice. J Neurosci 2010;30: 10086-10095.

75 Lanska DJ, Hoffmann RG: Seasonal variation in stroke mortality rates. Neurology 1999;52:984-990.

76 Nichol KL, Nordin J, Mullooly J, Lask R, Fillbrandt $\mathrm{K}$, Iwane $\mathrm{M}$ : Influenza vaccination and reduction in hospitalizations for cardiac disease and stroke among the elderly. N Engl J Med 2003;348:1322-1332.

77 Muhammad S, Haasbach E, Kotchourko M, Strigli A, Krenz A, Ridder DA, Vogel AB, Marti HH, Al-Abed Y, Planz O, Schwaninger $\mathrm{M}$ : Influenza virus infection aggravates stroke outcome. Stroke 2011;42:783-791.

-78 Rupp J, Kothe H, Mueller A, Maass M, Dalhoff K: Imbalanced secretion of IL-1beta and IL-1ra in Chlamydia pneumoniae-infected mononuclear cells from COPD patients. Eur Respir J 2003;22:274-279.
79 Endeman H, Meijvis SC, Rijkers GT, van Velzen-Blad H, van Moorsel CH, Grutters JC, Biesma DH: Systemic cytokine response in patients with community-acquired pneumonia. Eur Respir J 2011;37:1431-1438.

80 Calbo E, Alsina M, Rodriguez-Carballeira M, Lite J, Garau J: The impact of time on the systemic inflammatory response in pneumococcal pneumonia. Eur Respir J 2010;35: 614-618.

81 Kafka D, Ling E, Feldman G, Benharroch D, Voronov E, Givon-Lavi N, Iwakura Y, Dagan R, Apte RN, Mizrachi-Nebenzahl Y: Contribution of IL-1 to resistance to Streptococcus pneumoniae infection. Int Immunol 2008, 20:1139-1146.

82 Herold S, Tabar TS, Janssen H, Hoegner K, Cabanski M, Lewe-Schlosser P, Albrecht J, Driever F, Vadasz I, Seeger W, Steinmueller M, Lohmeyer J: Exudate macrophages attenuate lung injury by the release of IL-1 receptor antagonist in gram-negative pneumonia. Am J Resp Crit Care Med 2011;183:13801390.

83 Gasse P, Mary C, Guenon I, Noulin N, Char ron S, Schnyder-Candrian S, Schnyder B Akira S, Quesniaux VF, Lagente V, Ryffel B, Couillin I: IL-1r1/myd88 signaling and the inflammasome are essential in pulmonary inflammation and fibrosis in mice. J Clin Invest 2007;117:3786-3799.

84 Carrol ED, Payton A, Payne D, Miyajima F Chaponda M, Mankhambo LA, Banda DL, Molyneux EM, Cox H, Jacobson G, Carr DF, Molyneux ME, Stewart JP, Quinn JP, Hart CA, Ollier WE: The IL1rn promoter rs4251961 correlates with IL-1 receptor antagonist concentrations in human infection and is differentially regulated by gata-1. J Immunol 2011;186:2329-2335.

85 Bermejo-Martin JF, Martin-Loeches I, Rello $\mathrm{J}$, et al: Host adaptive immunity deficiency in severe pandemic influenza. Crit Care 2010; 14:R167.

86 Tanzi P, Cain K, Kalil A, Zierath D, Savos A, Gee JM, Shibata D, Hadwin J, Carter K, Becker K: Post-stroke infection: a role for IL1ra? Neurocritic Care;14:244-252.

87 Curti BD, Urba WJ, Longo DL, Janik JE, Sharfman WH, Miller LL, Cizza G, Shimizu M, Oppenheim JJ, Alvord WG, Smith JW 2nd: Endocrine effects of IL-1 alpha and beta administered in a phase $\mathrm{i}$ trial to patients with advanced cancer. J Immunother Emphasis Tumor Immunol 1996;19:142-148.

88 Sundar SK, Cierpial MA, Kilts C, Ritchie JC, Weiss JM: Brain IL-1-induced immunosuppression occurs through activation of both pituitary-adrenal axis and sympathetic nervous system by corticotropin-releasing factor. J Neurosci 1990;10:3701-3706.

89 Sullivan GM, Canfield SM, Lederman S, Xiao E, Ferin M, Wardlaw SL: Intracerebroventricular injection of interleukin-1 suppresses peripheral lymphocyte function in the primate. Neuroimmunomodulation 1997;4:12-18. $\checkmark 90$ Gelin JL, Moldawer LL, Iresjo BM, Lundholm KG: The role of the adrenals in the acute phase response to interleukin-1 and tumor necrosis factor-alpha. J Surg Res 1993;54:70-78.

-91 Medvedev AE, Lentschat A, Wahl LM, Golenbock DT, Vogel SN: Dysregulation of LPS-induced toll-like receptor 4-myd88 complex formation and IL-1 receptor-associated kinase 1 activation in endotoxin-tolerant cells. J Immunol 2002;169:5209-5216.

$\checkmark 92$ Beishuizen A, Thijs LG: Endotoxin and the hypothalamo-pituitary-adrenal (HPA) axis. J Endotox Res 2003;9:3-24.

$\checkmark 93$ Smith CJ EH, Hoadley ME, Hopkins SJ, Rothwell NJ TP, Udeh CT, Vail A: Interleukin-1 receptor antagonist reverses strokeassociated peripheral immunodepression. Int J Stroke 2010;5(suppl 3):3-13.

$\checkmark 94$ Kopf M, Bachmann MF, Marsland BJ: Averting inflammation by targeting the cytokine environment. Nat Rev Drug Discov 2010;9:703-718.

95 Diem R, Hobom M, Grotsch P, Kramer B, Bahr M: Interleukin-1 beta protects neurons via the interleukin-1 (IL-1) receptormediated akt pathway and by IL-1 receptorindependent decrease of transmembrane currents in vivo. Mol Cell Neurosci 2003; 22:487-500

96 Li Q, Zhang H, Chen Q, Quan N: Existence of seven human IL-1r1 promoters. J Inflamm Res 2010;17-24.

$\checkmark 97$ Quiniou C, Sapieha P, Lahaie I, Hou X, Brault S, Beauchamp M, Leduc M, Rihakova L, Joyal JS, Nadeau S, Heveker N, Lubell W, Sennlaub F, Gobeil F Jr, Miller G, Pshezhetsky AV, Chemtob S: Development of a novel noncompetitive antagonist of IL-1 receptor. J Immunol 2008;180:6977-6987.

$\checkmark 98$ Boutard N, Turcotte S, Beauregard K, Quiniou C, Chemtob S, Lubell WD: Examination of the active secondary structure of the peptide 101.10, an allosteric modulator of the interleukin-1 receptor, by positional scanning using beta-amino gamma-lactams. J Pept Sci 2011;17:288-296.

-99 Wang D, Zhang S, Li L, Liu X, Mei K, Wang $\mathrm{X}$ : Structural insights into the assembly and activation of IL-1beta with its receptors. Nature Immunol 2010;11:905-911.

100 Macleod MR, O'Collins T, Howells DW, Donnan GA: Pooling of animal experimental data reveals influence of study design and publication bias. Stroke 2004;35:12031208.

101 Allan SM, Tyrrell PJ, Rothwell NJ: Interleukin-1 and neuronal injury. Nat Rev 2005;5: 629-640.

102 Rothwell N: Interleukin-1 and neuronal injury: mechanisms, modification, and therapeutic potential. Brain Behav Immun 2003;17:152-157. 
103 Emsley HC, Smith CJ, Georgiou RF, Vail A, Hopkins SJ, Rothwell NJ, Tyrrell PJ: A randomised phase ii study of interleukin-1 receptor antagonist in acute stroke patients. J Neurol Neurosurg Psychiatry 2005;76: 1366-1372.

104 Cohen S, Hurd E, Cush J, Schiff M, Weinblatt ME, Moreland LW, Kremer J, Bear MB, Rich WJ, McCabe D: Treatment of rheumatoid arthritis with anakinra, a recombinant human interleukin-1 receptor antagonist, in combination with methotrexate: results of a twenty-four-week, multicenter, randomized, double-blind, placebo-controlled trial. Arthritis Rheum 2002; 46:614-624
105 Clark SR, McMahon CJ, Gueorguieva I, Rowland M, Scarth S, Georgiou R, Tyrrell PJ, Hopkins SJ, Rothwell NJ: Interleukin-1 receptor antagonist penetrates human brain at experimentally therapeutic concentrations. J Cereb Blood Flow Metab 2008;28:387-394.

106 Gueorguieva I, Clark SR, McMahon CJ, Scarth S, Rothwell NJ, Tyrrell PJ, Hopkins SJ, Rowland M: Pharmacokinetic modelling of interleukin-1 receptor antagonist in plasma and cerebrospinal fluid of patients following subarachnoid haemorrhage. $\mathrm{Br} \mathrm{J}$ Clin Pharmacol 2008;65:317-325.

107 Greenhalgh AD, Galea J, Denes A, Tyrrell PJ, Rothwell NJ: Rapid brain penetration of interleukin-1 receptor antagonist in rat cerebral ischaemia: pharmacokinetics, distribution, protection. Br J Pharmacol 2010; 160:153-159.
108 Galea J, Ogungbenro K, Hulme S, Greenhalgh A, Aarons L, Scarth S, Hutchinson P, Grainger S, King A, Hopkins SJ, Rothwell $\mathrm{N}$, Tyrrell P: Intravenous anakinra can achieve experimentally effective concentrations in the central nervous system within a therapeutic time window: results of a dose-ranging study. J Cereb Blood Flow Metab 2011;31:439-447.

109 Ischenko AM, Nikolaev BP, Kotova TV, Vorobeychikov EV, Konusova VG, Yakovleva LY: IL-1 receptor antagonist as an aerosol in inflammation. J Aerosol Med 2007;20:445459.

110 Pradillo HB, Drake C, Denes A, McColl BW, Rothwell NJ, Allan SM: Effect of IL-1 receptor antagonist (IL1-Ra) administered subcutaneously after experimental stroke (reperfusion time) in rats with different stroke risk factors. BRAIN 2011. Barcelona, 2011. 